\title{
The effect of QTL-rich region polymorphisms identified by targeted DNA-seq on pig production traits
}

\author{
Anna Stuczyńska ${ }^{3} \cdot K_{\text {Katarzyna Piórkowska }}^{1}$ (1) $\cdot$ Mirosław Tyra² $^{2}$ Kacper Żukowski ${ }^{4}$
}

Received: 26 September 2017 / Accepted: 24 March 2018 / Published online: 5 April 2018

(c) The Author(s) 2018

\begin{abstract}
The aim of the present study was to analyse the effect of PLCD4, PECR, FNI and PNKD mutations on pig productive traits and tested the usefulness of targeted enrichment DNA sequencing method as tool for preselection of genetic markers. The potential genetic markers for pig productive traits were identified by using targeted enrichment DNA sequencing of chromosome 15 region that is QTL-rich. The selected mutations were genotyped by using HRM, Sanger sequencing and PCR-ACRS methods. The association study was performed by using GLM model in SAS program and included over 500 pigs of 5 populations maintained in Poland. The variation (C/T) of PLCD4 gene affected feed conversion, intramuscular fat and water exudation. The $P N K D$ mutations were associated with texture parameters measured after cooking. In turn, the variation rs792423408 (C/T) in the $F N 1$ gene influenced toughness measured in semimembranosus muscle and growth traits that was observed particularly in Duroc breed. Summarizing, the investigated gene variants delivered valuable information that could be used during developing SNP microarray for genomic estimated breeding value procedure in pigs. Moreover, the study showed that the TEDNA-seq method could be used to preselect the molecular markers associated with pig traits. However, the further association study that included large number animal populations is necessary.
\end{abstract}

Keywords Targeted DNA sequencing · Genetic marker · Pork quality $\cdot$ Fibronectin

\section{Introduction}

One of the approaches based on next-generation sequencing (NGS) is targeted enrichment of genomic DNA (TEDNA-seq) sequencing, which allows the identification of a directly selected genomic region by using hybridization probes during DNA library preparation. Compared with

Electronic supplementary material The online version of this article (https://doi.org/10.1007/s11033-018-4170-3) contains supplementary material, which is available to authorized users.

Katarzyna Piórkowska

katarzyna.piorkowska@izoo.krakow.pl

1 Department of Animal Molecular Biology, National Research Institute of Animal Production, 32-083 Balice, Poland

2 Department of Pig Breeding, National Research Institute of Animal Production, 32-083 Balice, Poland

3 University of Huddersfield, School of Applied Science, CeBioR, Queensgate, HD1 3DH Huddersfield, Great Britain

4 Department of Cattle Breeding, National Research Institute of Animal Production, 32-083 Balice, Poland a whole-genome strategy, the cost and effort of TEDNAseq analysis can be lower because of selective recovery and subsequent sequencing. Targeted enrichment sequencing is mainly applied to whole-exome analysis, which enables the identification of many diseases or metabolic pathways [1]. However, the bioinformatics of TEDNA-seq is a big challenge due to the complex analysis that includes choosing the most suitable software, algorithm, and filtering parameters to avoid false positive gene variant calls [2].

On the other hand, based on the current release of the Pig QTL database, there are 17955 QTLs (quantitative trait loci)/associations identified from 576 publications that represent 635 different traits associated with meat and carcass traits, health, exterior, production and reproductive traits (http://www.animalgenome.org/cgi-bin/ QTLdb/SS/index). In pigs, chromosome 15 contains a region between the microsatellites $S W 1683$ and SW906 (79.3-89.3 cM, 127-135 Mbp) which is highly rich in QTLs associated with meat quality, fat content and growth traits. In this region, the abundance of QTLs related to meat quality traits, in particular meat texture, is the highest in comparison to other pig chromosomes. That SSC15 
region contains more than 60 genes, including $A B C A 12$, PRKAG3, MARCH4, DES, CYP27A1, OBSL1, IGFBP2 and IGFBP5, which have been already investigated for their relationship with meat quality and growth traits [3]. The PRKAG3 encode a muscle-specific isoform of the regulatory $\gamma$ subunit of adenosine monophosphate-activated protein kinase (AMPK) [4]. A missense mutation in the PRKAG3 gene was detected that affected the $\mathrm{pH}$ and meat colour in pigs [5]. In turn, the DES gene encodes a cytoskeletal protein called desmin, which is located in the outer periphery of the Z-disk in skeletal muscle fibres. This protein plays an important role in joining the neighbouring myofibrils and adhering them to the cell membrane [6]. Starkey et al. [7] postulate that there is a strong correlation between desmin degradation and increase in tenderness and water exudation in ovine meat products, but the desmin degradation was not researched in relation to pork. And the study of Piórkowska et al. [8] showed that the $A B C A 12$ promoter insertion affected daily gain, feed conversion and meat brightness. Although, that numerous genes located in the SSC15 region of interest has been analysed for their effect on pig traits, this region is still highly curious. Because, it probably contains unknown genetic markers associated with pork texture parameters and fat content.

Therefore, the aim of the present study was the analysis of PECR, FN1, PNKD and PLCD4 mutation effect on pig productive traits with particular emphasis on pork texture parameters. These mutations are located in the region on chromosome 15 and they were selected using TEDNA-seq method. The preliminary study was conducted by using two pig breeds Polish Landrace and Puławska that are significantly different in fat content, meat quality and growth traits. In turn, the main association study was performed by using over 500 pigs belonging to 5 pig populations maintained in Poland.

\section{Materials and methods}

\section{Animals}

All animals used in the investigation originated from different farms, were female and unrelated. They were delivered to Pig Test Station of National Research Institute of Animal Production located in Chorzelów, Mełno, Pawłowice, and Rossocha. All pigs were maintained under the same environmental and diet condition according to Pig Test Station procedure. They were fed ad libitum by initial weight at $30 \mathrm{~kg}$ and finished at $100 \pm 2 \mathrm{~kg}$. The growth traits were measured during Test and the body composition, fat content and meat quality parameters were assessed after slaughter according to Tyra and Żak et al. [9] and meat texture parameters as was described by Ropka-Molik et al. [10].

\section{DNA isolation}

The blood samples were collected during slaughter and stabilized by EDTA. DNA was isolated from whole blood by Sherlock AX (A\&A Biotechnology) kit.

\section{Targeted enrichment DNA sequencing}

The TEDNA-seq analysis, performed for another study [11], included 16 pigs of the Polish Landrace $(n=8)$ and Puławska $(n=8)$ breeds, which differ in growth, meat quality and fat content traits. The enrichment technique applied in this approach was RNA hybrid capture ( $1 \times$ tiling). The hybridization probes for the region of interest with exclusion of repeat-masked elements [12], which reduce the recovery of undesirable products, were designed by the Agilent team. Each library was indexed with a unique adaptor that enabled identification of most mutations for specific animals and then made it possible to perform an association study on chosen pigs. Filtered sequences were aligned to the Sus scrofa genome (Sscrofa10.2 assembly).

\section{Selection of potential biomarkers}

After performing TEDNA-seq on 16 chosen pigs, the analysis provided information about all gene variants in the SSC15 region, our region of interest, which is QTL-rich. The preliminary association analysis was conducted using LRT test in R-project. The LRT test was used to compare likelihood of linear null model versus alternative mode with SNP fixed effect.

$\mathrm{LRT}=-2 \log _{e}\left(\frac{\mathcal{L}_{s}(\hat{\theta})}{\mathcal{L}_{g}(\hat{\theta})}\right)$

The difference in log-likelihoods was compared with a Chi-squared distribution. The selection criteria of gene variants for further analysis were: $P$ value $\leq 0.05$ of LRT test obtained for at least few investigated pig productive traits and the relationship of identified mutations with genes likely involved in shaping the pig phenotype. The functional analysis of genes having significant mutations was carried out by Panther, STRING and KEGG. All selected gene variants were validated by Sanger sequencing. 


\section{Genotyping of selected mutations with the potential to become biomarkers}

Five mutations with high potential were selected. The genotyping was performed for 535 pigs of 5 breeds: Puławska, Polish Landrace, Polish Large White, Pietrain and Duroc by using different molecular techniques.

The missense variant rs $792423408(\mathrm{C} / \mathrm{T})$ of the $F N 1$ gene and the upstream gene variant $\mathrm{rs} 343851532(\mathrm{C} / \mathrm{T})$ of the PECR gene were genotyped by the high-resolution melting (HRM) technique. The KAPA ${ }^{\mathrm{TM}}$ HRM FAST PCR Kit (Kapa Biosystems, USA) was used to perform the HRM method on a QuantStudio 7 Flex Real-Time PCR System (Thermo Scientific, USA). The mutation rs324680963 $(\mathrm{C} / \mathrm{T})$, located upstream of the PLCD4 gene, was analysed by the PCR-ACRS method. PCR was performed using the AmpliTaq ${ }^{\circledR} 360$ Gold Master Mix Kit (Thermo Scientific, USA) on a Mastercycler ${ }^{\circledR}$ Nexus Gradient (Eppendorf), and then the PCR product was digested in $37{ }^{\circ} \mathrm{C}$ with a mixture of $4 \mathrm{U}$ restriction enzyme RsaI (New England Biolabs, USA). The missense rs329501722 (C/A) and the frameshift rs792243103 (-/C) in the first exon of the PNKD gene variants were sequenced by Sanger sequencing using the BigDye ${ }^{\circledR}$ Terminator v3.1 Sequencing Kit (Thermo Scientific, USA) on a 3500XL Genetic Analyzer (Applied Biosystems, USA).

\section{Statistical analysis}

The gene variant effects on 535 gilts were estimated by using the GLM procedure (SASv.8.02). The final model was

$\mathrm{Y}_{\mathrm{ijk}}=\mu+\mathrm{d}_{\mathrm{i}}+\mathrm{b}_{\mathrm{j}}+\mathrm{s}_{\mathrm{k}}+\mathrm{e}_{\mathrm{ijk}}$

where, $Y_{i j k}$ is the observation, $\mu$ is the overall mean of the trait, $d_{i}$ is the fixed effect of the $k_{\text {th }}$ genotypes of gene, $b_{j}$ is the fixed effect of breed, $s_{k}$ is the fixed effect of pig station, $\mathrm{e}_{\mathrm{ijk}}$ is the random error.

To estimate significance differences between means, the Least Mean Squares (LSM) test was used. All results are shown as $\mathrm{LSM} \pm \mathrm{SE}$.

\section{Results}

\section{The selection of interesting gene variants after targeted enrichment sequencing of DNA}

By using LRT test and functional analysis five mutations of PECR, FN1, PNKD and PLCD4 genes (Table 1) showing possible association with pig production traits were selected. The whole gene variant list with $P$ values after LRT test is available by link goo.gl/dXenef.

\section{Validation of significant gene variants by using the Sanger sequencing method}

The validation of identified significant gene variants was performed by Sanger sequencing method using a 3500XL Genetic Analyzer (Applied Biosystems, USA) to verify their position on porcine chromosome 15. Chromatograms that confirmed the presence of variations in chosen genes were shown in Fig. 1.

\section{The effect of significant gene variants on pig productive traits}

\section{PLCD4 gene}

The PCR-ACRS method was used to genotype the mutation (rs324680963) in the gene PLCD4. In was observed that alternate $\mathrm{T}$ allele occurred with $13 \%$ frequency and homozygotes TT constituted only 4\%. The highest number of pig individuals with the TT genotype has been observed in Polish Landrace (7\%). In turn, in the Duroc, TT pigs were not present (Table S1).

The variation $(\mathrm{C} / \mathrm{T})$ of the PLCD4 gene significantly influenced feed conversion $(\mathrm{kg} / \mathrm{kg})$, intramuscular fat (IMF) and water exudation. The individuals with the $\mathrm{CC}$ genotype presented the highest feed conversion values in comparison to pigs with the other genotypes. Moreover, TT Polish Landrace pigs showed higher IMF $(P<0.05)$ than the other investigated pigs, which revealed similar values of IMF. In
Table 1 Chosen variation of genes that could be associated with pig production traits

\begin{tabular}{llllll}
\hline ID number $^{\mathrm{a}}$ & Position on SSC15 $^{\mathrm{b}}$ & $\begin{array}{l}\text { Reference } \\
\text { allele }\end{array}$ & $\begin{array}{l}\text { Alternate } \\
\text { allele }\end{array}$ & Localization or effect & Gene \\
\hline rs324680963 & 133641482 & $\mathrm{C}$ & $\mathrm{T}$ & Upstream gene variant & PLCD4 \\
rs792423408 & 130416725 & $\mathrm{C}$ & $\mathrm{T}$ & Missense variant & FN1 \\
rs343851532 & 131216842 & $\mathrm{C}$ & $\mathrm{T}$ & Upstream gene variant & PECR \\
rs329501722 & 133370271 & $\mathrm{C}$ & $\mathrm{A}$ & Missense variant & $P N K D$ \\
rs792243103 & 133370291 & - & $\mathrm{C}$ & Frameshift variant & $P N K D$ \\
\hline
\end{tabular}

${ }^{\mathrm{a}}$ ID number of SNP database (NCBI)

${ }^{b}$ position on SSC15 according to Sscrofa 10.2 assembly 


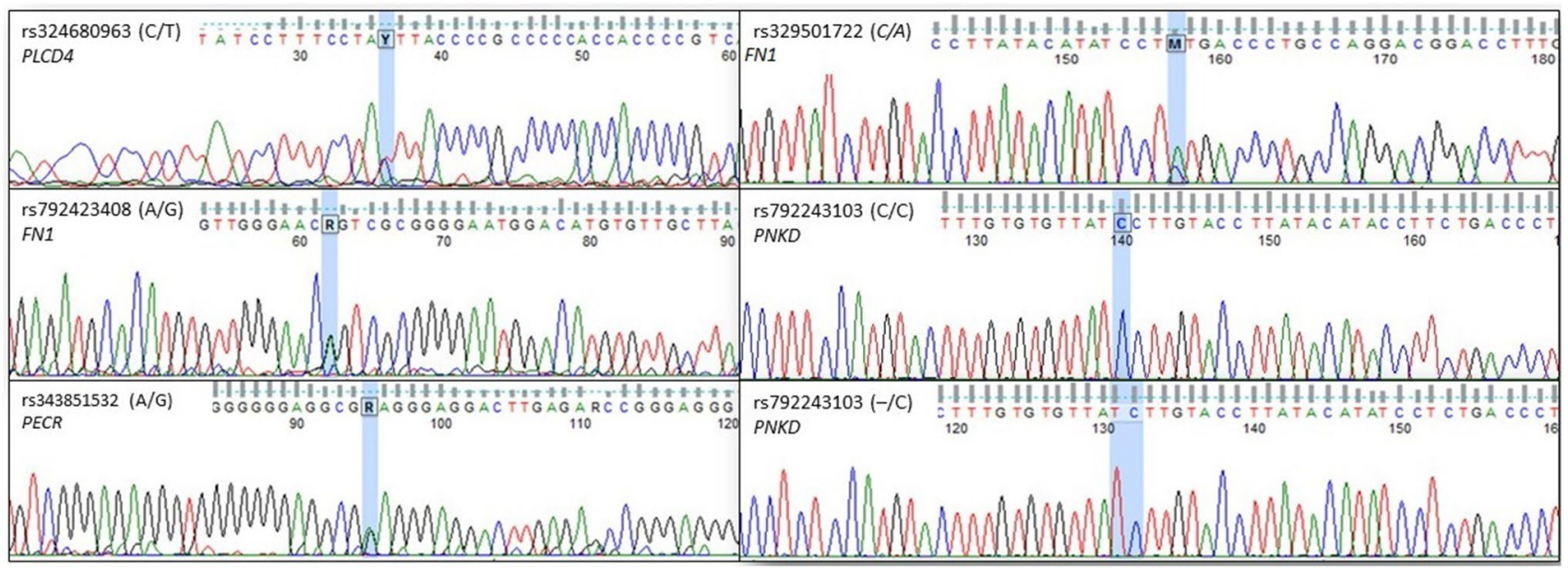

Fig. 1 The chromatogram showing the variations of PLCD4, FN1, PECR and PNKD genes

Table $2 \mathrm{LSM} \pm$ S.E. for chosen interesting pig traits by PLCD4 genotypes, which presented the significant effect or trend

\begin{tabular}{|c|c|c|c|c|c|c|c|c|c|c|}
\hline \multirow[t]{2}{*}{ Traits } & \multirow{2}{*}{$\begin{array}{l}\text { Geno- } \\
\text { type } \\
\text { PLCD4 }\end{array}$} & \multirow[t]{2}{*}{ PLW } & \multirow[t]{2}{*}{ PUL } & \multirow[t]{2}{*}{ PL } & \multirow[t]{2}{*}{ DUR } & \multirow[t]{2}{*}{ PIET } & \multirow[t]{2}{*}{ Total $^{1}$} & \multicolumn{3}{|c|}{ GLM significance } \\
\hline & & & & & & & & PLCD4 & Breed & Pig test station \\
\hline Feed conversion $(\mathrm{kg} / \mathrm{kg})$ & $\begin{array}{l}C C \\
C T \\
T T\end{array}$ & $\begin{array}{l}2.46^{ \pm 0.07} \\
2.48^{ \pm 0.08} \\
2.31^{ \pm 0.10}\end{array}$ & $\begin{array}{l}2.90^{ \pm 0.02} \\
2.94^{ \pm 0.05} \\
3.12^{ \pm 0.25}\end{array}$ & $\begin{array}{l}2.71^{ \pm 0.03} \\
2.79^{ \pm 0.03} \\
2.82^{ \pm 0.07}\end{array}$ & $\begin{array}{l}2.82^{ \pm 0.04} \\
2.99^{ \pm 0.17} \\
-\end{array}$ & $\begin{array}{l}2.89^{ \pm 0.07} \\
3.08^{ \pm 0.12} \\
3.13^{ \pm 0.20}\end{array}$ & $\begin{array}{l}2.80^{ \pm 0.04} \mathrm{~A} \\
2.88^{ \pm 0.05} \mathrm{~B} \\
2.88^{ \pm 0.07} \mathrm{~B}\end{array}$ & $* *$ & $* * *$ & $* * *$ \\
\hline IMF & $\begin{array}{l}C C \\
C T \\
T T\end{array}$ & $\begin{array}{l}1.24^{ \pm 0.09} \\
1.23^{ \pm 0.10} \\
1.18^{ \pm 0.14}\end{array}$ & $\begin{array}{l}1.16^{ \pm 0.03} \\
1.30^{ \pm 0.07} \\
1.04^{ \pm 0.32}\end{array}$ & $\begin{array}{l}1.18^{ \pm 0.02} \mathrm{a} \\
1.18^{ \pm 0.03} \mathrm{a} \\
1.32^{ \pm 0.05} \mathrm{~b}\end{array}$ & $\begin{array}{l}2.35^{ \pm 0.07} \\
- \\
-\end{array}$ & $\begin{array}{l}2.18^{ \pm 0.16} \\
2.47^{ \pm 0.29} \\
-\end{array}$ & $\begin{array}{l}2.24^{ \pm 0.07} \\
2.36^{ \pm 0.09} \\
2.45^{ \pm 0.13}\end{array}$ & * & $* * *$ & $* * *$ \\
\hline Water exudation & $\begin{array}{l}C C \\
C T \\
T T\end{array}$ & $\begin{array}{l}30.4^{ \pm 3.24} \mathrm{a} \\
36.3^{ \pm 3.57} \mathrm{~b} \\
33.2^{ \pm 4.93} \mathrm{ab}\end{array}$ & $\begin{array}{l}33.5^{ \pm 0.76} \\
34.5^{ \pm 1.46} \\
-\end{array}$ & $\begin{array}{l}35.7^{ \pm 0.75} \\
37.8^{ \pm 0.78} \\
37.0^{ \pm 1.81}\end{array}$ & $\begin{array}{l}31.5^{ \pm 0.83} \\
- \\
-\end{array}$ & $\begin{array}{l}32.5^{ \pm 1.52} \\
29.8^{ \pm 3.08} \\
26.8^{ \pm 7.43}\end{array}$ & $\begin{array}{l}32.8^{ \pm 1.10} \\
35.1^{ \pm 1.29} \\
33.9^{ \pm 2.07}\end{array}$ & $* *$ & $* * *$ & $* * *$ \\
\hline Carcass yield & $\begin{array}{l}C C \\
C T \\
T T\end{array}$ & $\begin{array}{l}77.0^{ \pm 1.51} \\
77.8^{ \pm 1.64} \\
78.3^{ \pm 2.13}\end{array}$ & $\begin{array}{c}75.6^{ \pm 0.28} \\
77.2^{ \pm 0.63} \\
73.2^{ \pm 3.04}\end{array}$ & $\begin{array}{l}76.2^{ \pm 0.29} \\
76.5^{ \pm 0.33} \\
77.5^{ \pm 0.77}\end{array}$ & $\begin{array}{l}75.8^{ \pm 0.28} \\
76.9^{ \pm 1.14} \\
-\end{array}$ & $\begin{array}{l}77.1^{ \pm 0.60} \\
76.7^{ \pm 1.06} \\
78.9^{ \pm 1.85}\end{array}$ & $\begin{array}{l}76.9^{ \pm 0.47} \\
77.5^{ \pm 0.54} \\
78.1^{ \pm 0.82}\end{array}$ & $*$ & $* * *$ & $* * *$ \\
\hline Backfat thickness & $\begin{array}{l}C C \\
C T \\
T T\end{array}$ & $\begin{array}{l}1.65^{ \pm 0.17} \\
1.65^{ \pm 0.18} \\
1.76^{ \pm 0.24}\end{array}$ & $\begin{array}{l}1.58^{ \pm 0.03} \\
1.52^{ \pm 0.07} \\
2.20^{ \pm 0.36}\end{array}$ & $\begin{array}{l}1.24^{ \pm 0.04} \\
1.29^{ \pm 0.04} \\
1.35^{ \pm 0.10}\end{array}$ & $\begin{array}{l}1.49^{ \pm 0.04} \\
1.84^{ \pm 0.15} \\
-\end{array}$ & $\begin{array}{l}1.13^{ \pm 0.06} \\
1.15^{ \pm 0.10} \\
1.15^{ \pm 0.17}\end{array}$ & $\begin{array}{l}1.48^{ \pm 0.05} \\
1.50^{ \pm 0.06} \\
1.60^{ \pm 0.09}\end{array}$ & ns & $* * *$ & $* * *$ \\
\hline
\end{tabular}

Allele: $C$ wild, $T$ mutation. Values with the same superscripts belong to the same statistical group $(\mathrm{A}, \mathrm{B}=P<0.01, \mathrm{a}, \mathrm{b}=P<0.05) . P L W$ Polish Large White, $P L$ Polish Landrace, DUR Duroc, PIET Pietrain, IMF intramuscular fat

${ }^{1}$ Means for pig traits independent on breed

turn, CC Polish Large White individuals characterized by the lowest values of water exudation ( -6 units, $P<0.05)$. This trend was observed for all breeds except Pietrain. The opposite trend was identified for an average backfat thickness, where TT pigs seemed to have thicker backfat (Table 2).

\section{FN1 gene}

To genotype the variation rs792423408 (C/T) in the FNI gene, the HRM method was applied. It was observed that the majority of investigated pigs belonged to CC homozygotes, CT heterozygous genotype was identified in just $10 \%$ pigs and TT individuals were absent. And in the Pietrain, only one CC genotype was detected. The frequencies of the genotypes are shown in (Table S2).

The influence of the FN1 gene on the toughness of cooked semimembranosus muscle was observed with a significance of $P<0.05$ (Table 3 ). In all investigated breeds, the CT heterozygotes were characterized by higher values of toughness $(+16 \mathrm{~N} / \mathrm{mm} / \mathrm{s})$ than the CC homozygotes. The overall analysis showed a tendency that the $\mathrm{CC}$ pigs characterized by higher daily gain and achieved faster slaughter mass than CT pigs. Significant results were observed for the Duroc pigs, where CC pigs had $83 \mathrm{~g}$ higher daily gain $(P<0.05)$ and achieved a faster finish day $(P<0.01,26$ days earlier $)$ than 


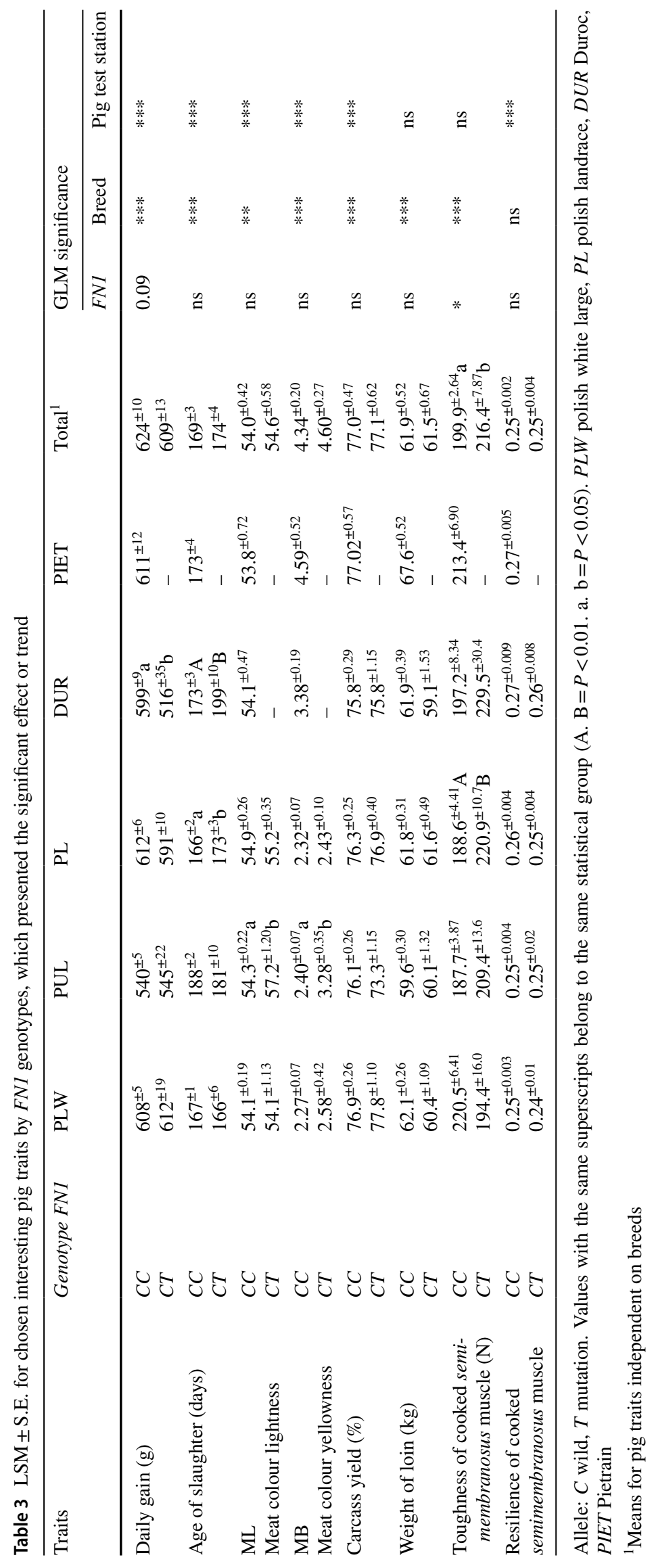


the CT Duroc pigs. Similarly in the Polish Landrace, where the CC pigs finished the Test 6 days faster than CT pigs $(P<0.05)$. In regards to meat quality traits, the CT Puławska pigs had higher values of both meat lightness and yellowness than the $\mathrm{CC}$ homozygotes $(P<0.05)$. Moreover, it was observed that rs792423408 (C/T) FN1 mutation probably affected meat texture parameters. Significant results were detected in Polish Landrace where heterozygotes showed $15 \%$ higher values of toughness than the $\mathrm{CC}$ pigs $(P<0.01)$.

\section{PECR gene}

The upstream PECR rs343851532 (C/T) variant was genotyped by the same as FNl mutation the HRM method. The analysis of five Polish pig breeds showed low frequency of $\mathrm{C}$ allele (13\%) in these populations. In all breeds only two genotypes TT and CT were observed (Table S3).

The conducted association study showed that PECR rs $343851532(\mathrm{C} / \mathrm{T})$ mutation affected meat content. The CC pigs characterized by higher carcass yield and weight of loin than the CT individuals. It was particularly observed in the Duroc pigs, where CC Duroc showed $300 \mathrm{~g}$ higher weight of loin than those with the CT genotype. In turn, in the Pietrain breed CC pigs presented $2 \%$ higher meat percentage than the heterozygotes (Table 4). In regards to meat texture parameters just tendencies were identified.

\section{PNKD gene}

The variations rs329501722 (C/A) and rs792243103 (-/C) of the $P N K D$ gene were genotyped using Sanger sequencing on a 3500 Genetic Analyzer (Applied Biosystems, USA) (Fig. 1).

The alternate A allele frequency of rs 329501722 PNKD mutation was low and accounted only $13 \%$. The $5 \%$ of investigated pigs revealed AA genotype and $24 \%$ belonged to heterozygotes (Table $\mathrm{S} 4$ ).

The association analysis showed that the PNKD rs329501722 (C/A) mutation influenced feed conversion, water exudation, resilience, cohesiveness for semimembranosus (ham) muscle and weight of loin. All investigated AA pigs showed higher water exudation $(P<0.01)$, resilience and cohesiveness values measured in cooked semimembranosus, and higher weight of loin (approx. $200 \mathrm{~g}, P<0.05$ ). It was particularly observed in PLW and PUL pigs, where AA pigs characterized by 5 and 10 units higher values of water exudation $(P<0.01)$ than the CC individuals. In the Duroc and Pietrain breeds the AA pigs were absent. Nevertheless, in the Duroc was observed that $\mathrm{AC}$ pigs showed lower values of daily gains (close to $100 \mathrm{~g}, P<0.05$ ) than the $\mathrm{CC}$ pigs. In the Polish Landrace, opposite tendencies were observed. The AA PL pigs exhibited the lowest growth performance parameters such as the $70 \mathrm{~g}$ lower daily gain $(P<0.05)$ and higher feed/gain ratio $(P<0.01)$, but their meat had higher IMF content $(P<0.05)$ than pigs with the other genotypes (Table 5).

The second identified in PNKD gene rs792243103 (-/C) mutation was more frequent. In investigated pig populations prevailed heterozygotes (46\%) and the C deletion in both alleles occurred with $17 \%$ frequency (Table S5). The present study showed that this INDEL mutation affected the growth traits particularly in PUL pigs, which belong to native breeds and were not under selective pressure. In the PUL breed, the absence of $\mathrm{C}$ in position 202 of the $P N K D$ transcript caused

Table $4 \mathrm{LSM} \pm$ S.E. for chosen interesting pig traits by PECR genotypes, which presented the significant effect

\begin{tabular}{|c|c|c|c|c|c|c|c|c|c|c|}
\hline \multirow[t]{2}{*}{ Traits } & \multirow{2}{*}{$\begin{array}{l}\text { Geno- } \\
\text { type } \\
\text { PECR }\end{array}$} & \multirow[t]{2}{*}{ PLW } & \multirow[t]{2}{*}{ PUL } & \multirow[t]{2}{*}{ PL } & \multirow[t]{2}{*}{ DUR } & \multirow[t]{2}{*}{ PIET } & \multirow[t]{2}{*}{ Total $^{1}$} & \multicolumn{3}{|c|}{ GLM significance } \\
\hline & & & & & & & & $P E C R$ & Breed & Pig test station \\
\hline Carcasss yield (\%) & $\begin{array}{l}C C \\
C T\end{array}$ & $\begin{array}{l}77.6^{ \pm 0.31} \mathrm{~A} \\
75.8^{ \pm 0.42} \mathrm{~B}\end{array}$ & $\begin{array}{l}75.8^{ \pm 0.29} \\
76.3^{ \pm 0.55}\end{array}$ & $\begin{array}{l}76.2^{ \pm 0.24} \mathrm{a} \\
77.3^{ \pm 0.45} \mathrm{~b}\end{array}$ & $\begin{array}{l}75.9^{ \pm 0.31} \\
75.4^{ \pm 0.55}\end{array}$ & $\begin{array}{l}76.7^{ \pm 0.64} \\
77.5^{ \pm 0.74}\end{array}$ & $\begin{array}{l}77.0^{ \pm 0.48} \\
76.9^{ \pm 0.51}\end{array}$ & ns & $* * *$ & $* * *$ \\
\hline Weigth of loin $(\mathrm{kg})$ & $\begin{array}{l}C C \\
C T\end{array}$ & $\begin{array}{l}6.05^{ \pm 0.07} \mathrm{a} \\
5.81^{ \pm 0.10} \mathrm{~b}\end{array}$ & $\begin{array}{l}5.66^{ \pm 0.06} \\
5.72^{ \pm 0.11}\end{array}$ & $\begin{array}{l}5.94^{ \pm 0.06} \\
6.05^{ \pm 0.11}\end{array}$ & $\begin{array}{l}6.11^{ \pm 0.06} \mathrm{~A} \\
5.77^{ \pm 0.11} \mathrm{~B}\end{array}$ & $\begin{array}{l}6.56^{ \pm 0.12} \\
6.64^{ \pm 0.14}\end{array}$ & $\begin{array}{l}6.43^{ \pm 0.10} \\
6.38^{ \pm 0.11}\end{array}$ & ns & $* * *$ & $* * *$ \\
\hline Meat percentage $(\%)$ & $\begin{array}{l}C C \\
C T\end{array}$ & $\begin{array}{l}61.6^{ \pm 0.53} \\
62.6^{ \pm 0.56}\end{array}$ & $\begin{array}{l}59.7^{ \pm 0.33} \\
59.7^{ \pm 0.62}\end{array}$ & $\begin{array}{l}61.8^{ \pm 0.30} \\
61.7^{ \pm 0.57}\end{array}$ & $\begin{array}{l}61.7^{ \pm 0.45} \\
62.1^{ \pm 0.78}\end{array}$ & $\begin{array}{l}68.1^{ \pm 0.59} \mathrm{a} \\
66.3^{ \pm 0.69} \mathrm{~b}\end{array}$ & $\begin{array}{l}61.8^{ \pm 0.53} \\
61.8^{ \pm 0.56}\end{array}$ & ns & $* * *$ & ns \\
\hline $\begin{array}{l}\text { Toughness of cooked } \\
\text { semimembranosus } \\
\text { muscle }(\mathrm{N})\end{array}$ & $\begin{array}{l}C C \\
C T\end{array}$ & $\begin{array}{l}217.0^{ \pm 7.89} \\
223.7^{ \pm 10.2}\end{array}$ & $\begin{array}{l}191.3^{ \pm 4.38} \\
179.5^{ \pm 8.38}\end{array}$ & $\begin{array}{l}194.4^{ \pm 4.52} \\
202.8^{ \pm 11.8}\end{array}$ & $\begin{array}{l}199.6^{ \pm 9.53} \\
206.2^{ \pm 17.7}\end{array}$ & $\begin{array}{l}212.0^{ \pm 8.68} \\
209.4^{ \pm 10.0}\end{array}$ & $\begin{array}{l}200.2^{ \pm 2.86} \\
204.0^{ \pm 5.23}\end{array}$ & ns & $* * *$ & ns \\
\hline $\begin{array}{l}\text { Chewiness of cooked } \\
\text { semimembranosus } \\
\text { muscle }\end{array}$ & $\begin{array}{l}C C \\
C T\end{array}$ & $\begin{array}{l}4.71^{ \pm 0.32} \\
5.08^{ \pm 0.37}\end{array}$ & $\begin{array}{l}4.22^{ \pm 0.21} \\
3.74^{ \pm 0.48}\end{array}$ & $\begin{array}{l}4.30^{ \pm 0.26} \\
4.05^{ \pm 0.38}\end{array}$ & $\begin{array}{l}5.17^{ \pm 0.57} \\
4.24^{ \pm 1.08}\end{array}$ & $\begin{array}{l}6.26^{ \pm 0.36} \\
6.22^{ \pm 0.77}\end{array}$ & $\begin{array}{l}4.66^{ \pm 0.14} \\
4.62^{ \pm 0.24}\end{array}$ & ns & $* * *$ & ns \\
\hline
\end{tabular}

Allele: $C$ wild, $T$ mutation. Values with the same superscripts belong to the same statistical group $(\mathrm{A}, \mathrm{B}=P<0.01, \mathrm{a}, \mathrm{b}=P<0.05) . P L W$ Polish Large White, PL Polish Landrace, DUR Duroc, PIET Pietrain

${ }^{1}$ Means for pig traits independent on breeds 


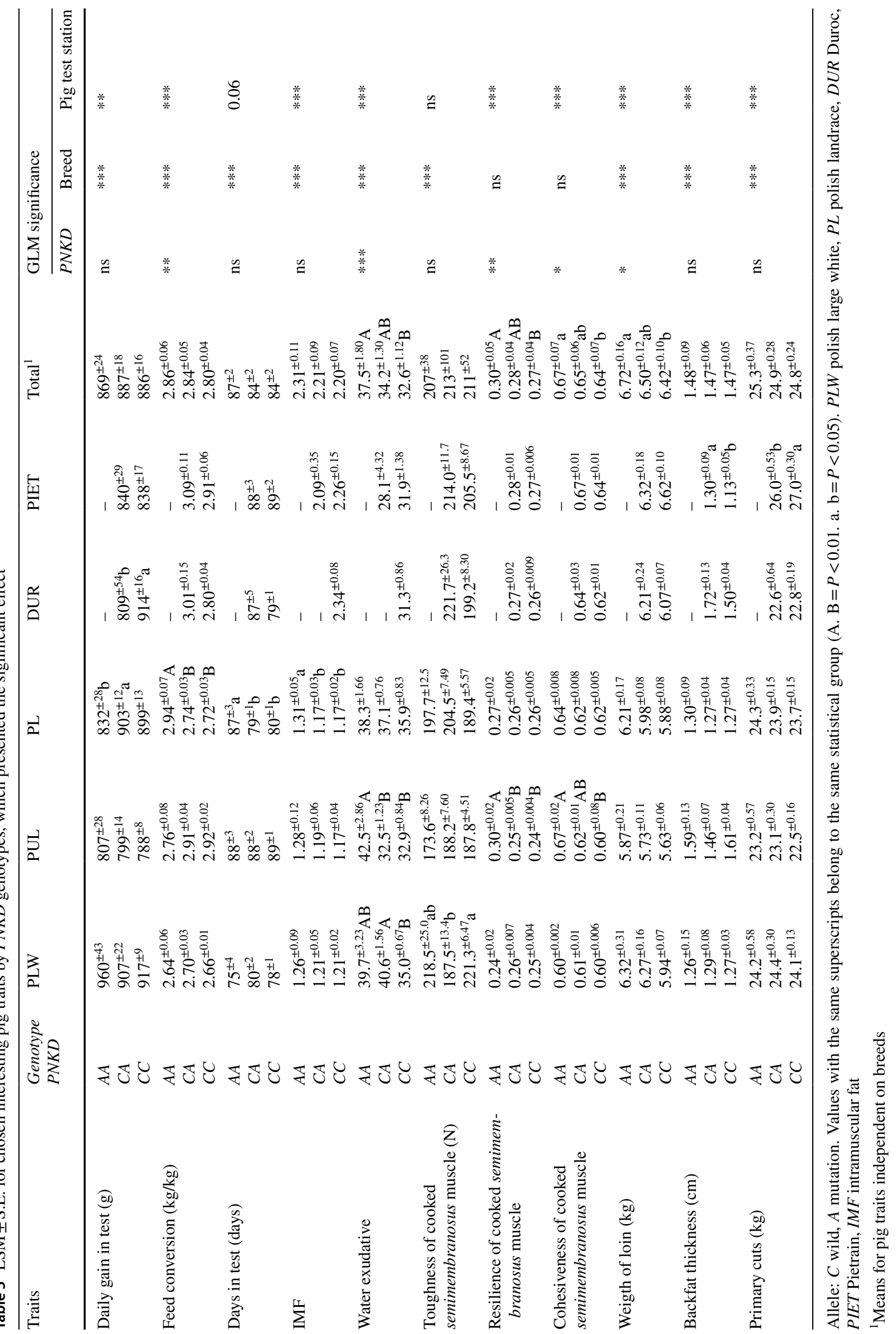


a slight decrease in daily feed intake. Those pigs were also characterized by higher toughness values measure in the semimembranosus muscle $(P<0.05)$ and resilience parameters. Moreover, this mutation affected meat yellowness and carcass yield $(P<0.05)$. The pigs with $\mathrm{C}$ insertions in both alleles presented higher values of meat yellowness $(P<0.05)$ and carcass yield and lower toughness values $(-12 \mathrm{~N} / \mathrm{mm} / \mathrm{s}$, $P<0.05)$ than pigs with other genotypes. The CC PL individuals showed the lowest carcass yield $(-3 \%, P<0.05)$, weight of loin $(-300 \mathrm{~g}, P<0.05)$ and primer cuts $(-700 \mathrm{~g}$, $P<0.05)$. On the other hand, in the CC Pietrain pigs significantly lower $\mathrm{pH}$ value measured in longissimus dorsi muscle in comparison to $-/-$ pigs (Table 6 ).

\section{Discussion}

The present study examined the targeted enrichment DNA sequencing method as tool for preselection of potential genetic markers. The positive results of the analysis could lead to the discovery of new possible ways to use this novel, fast and cost-effective technique. By using this method and functional analysis, five potential genetic markers were selected and included into downstream association study to show their effects on porcine productive traits.

In position -123 bp of the pig PLCD4 gene, one mutation (rs324680963) was identified that can introduce changes to the PLCD4 promoter region or in the sequence that enhances or silences gene expression. The analysis using the PROMO3 freeware showed that this mutation can affect the binding of numerous transcription factors (TFs). The PLCD4 gene encodes phospholipase $\mathrm{C}$ delta 4 , which activates $\mathrm{Ca}^{2+}$ ions during the leptin signalling pathway and induces the activity of NPY neurons and possibly affects feed intake. Additionally, phospholipase C participates indirectly in the thyroid hormone signalling pathway, which controls the metabolism of carbohydrates, proteins and lipids, thus having a potential influence on the growth traits [13]. In the present study, the upstream gene variant in the PLCD4 gene showed a significant impact on the feed conversion, IMF, water exudation and carcass yield. The CC homozygotes presented lower feed conversion than the pigs with other genotypes. However, the influence on feed intake was not observed. These results suggest that the identified mutation has not altered PLCD4 expression or that the phospholipase $\mathrm{C}$ delta 4 does not play such an important role in leptin signalling pathways, which was reflected in the phenotype. Nevertheless, it was shown that there is some significance in relation to feed conversion that is connected to the metabolism rate, thus implicating that this gene could play a meaningful role in the regulation of metabolism via the thyroid signalling pathway. Such a hypothesis could be explained by the research carried out by Onteru et al. [14] that showed the relationship between lipid metabolism and residual feed intake in Yorkshire pigs. In turn, Piórkowska et al. [15] proposed the PLCD4 gene as a candidate gene for meat quality traits such as IMF and fat content because of the probable connection with fatty acid metabolism. Our research also showed a high impact of the PLCD4 gene on IMF and water exudation, which should be further developed in studies included other pig breeds.

Another interesting gene variant that was located $-23 \mathrm{bp}$ upstream of the PECR gene seemed to be highly promising and was tested in the present study as a potential biomarker. Because the analysis of predicting the transcription factor binding sites by PROMO3 determined that the replacement of cytosine to thymine causes the loss of binding sites for 14 transcription factors and generates new binding sites for 5 novel TFs, this variant should significantly affect the $P E C R$ gene expression. The PECR encodes peroxisomal trans-2-enoyl-CoA reductase that is involved in fatty acid chain elongation and biosynthesis of unsaturated fatty acids. This reductase has high affinity to fatty acids with chain lengths up to 16 carbons [16]. A recent study by Huttlin et al. [17] postulated that PECR interacts with actin alpha 2 (ACTA2), which is involved in actin cytoskeleton and calcium signalling pathways, among others. It is possible that PECR, by interacting with ACTA2, can indirectly influence the growth traits, or more likely, it can have an impact on meat quality traits such as IMF and fat content because of its main function. This hypothesis was also confirmed by Sadkowski et al. [18], who researched novel genes that can be correlated with higher IMF. They found that the PECR gene is one of the novel genes that can be implicated in beef marbling. Another study supporting the participation of the PECR gene in fat deposition was carried out by Kärst et al. [19], where they investigated the effect of the PECR gene on shaping the intramuscular fat level and water holding capacity values in mice with high muscle mass. In turn, Piórkowska et al. [20] analysed the PECR145T >C mutation effect on pork quality in Polish pig breeds and found thicker backfat, lower loin intramuscular fat content, lower texture parameter values, and higher PECR expression measured in the longissimus dorsi muscle in pigs with the TT genotype. Therefore, they recommended the PECR gene as one of the candidate genes influencing fat mass. In the present study, -23 bp upstream of the PECR gene mutation affected only meat content traits. The effect on fat or IMF content were not observed. It suggests that this mutation does not regulate PECR expression. However, according to the latest pig genome release (Sscrofa11.1 assembly), this mutation is located also in 5 upstream regions of XRCC5 and FAM169 genes, therefore it could be associated with controlling their expression. Nevertheless, the abundance of publications with significant results focused on the function of the 


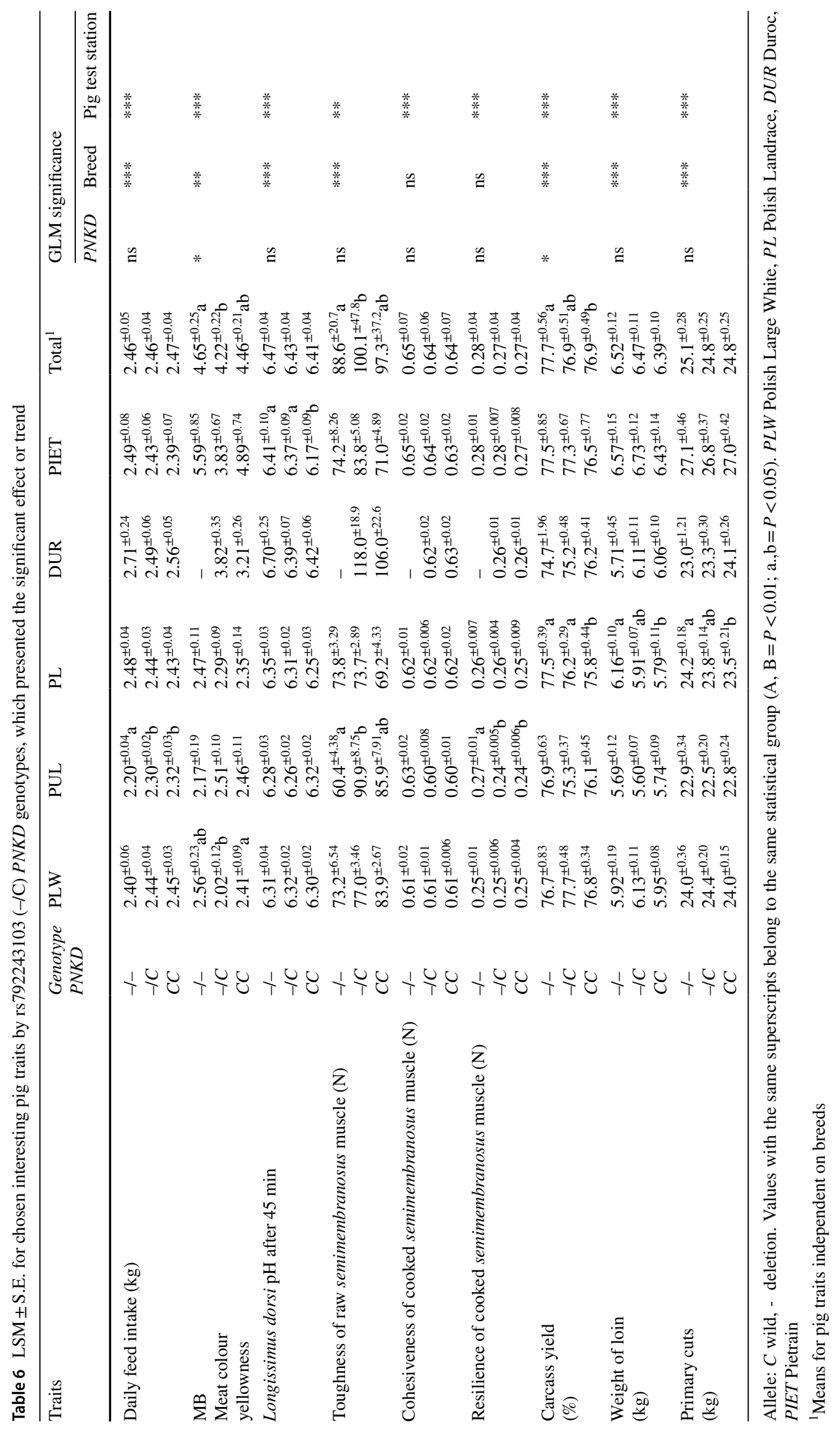


$P E C R$ gene in fat deposition in different animals suggests that the $P E C R$ polymorphisms could negatively influence pig productive traits by increasing the fat content. Therefore PECR mutations should be further investigated.

Another gene variation investigated in the present study was a missense variant in the FN1 gene (rs792423408). This type of mutation is highly interesting because it leads to an alteration in the amino acid sequence, which could influence the protein function. The SIFT tool, available in the Ensembl database, predicted that the identified missense mutation belongs to a deleterious gene variant located in the DNA sequence encoding important protein domains. The FN1 gene encodes fibronectin 1, which is involved in multiple pathways in the organism, the most interesting of which are the integrin pathway, extracellular matrix-receptor interaction, and regulation of actin cytoskeleton. The main function of fibronectin 1 is to bind cell surfaces and various compounds including collagen, fibrin, and actin as they participate in creating the extracellular matrix and basement membrane [21]. Fibronectins take part in cell adhesion and motility but also in opsonization, wound healing, and maintenance of cell shape [22, 23]. In the present study, it was observed that the missense variant of the FNl gene influenced the toughness values measured in cooked semimembranosus muscle $(P<0.05)$. In turn, Cassar-Malek et al. [24] investigated the effect of myostatin in double-muscled cattle, and its connection with $F N 1$ indicated that the fibronectin 1 gene is down-regulated in double-muscled cattle. This result suggests that $F N 1$ expression is switched off when massive muscle growth occurs. Moreover, Ponsuksili et al. [25], searching for the genes that can influence the water holding capacity in Duroc and Pietrain pigs, found that the FN1 gene has a negative impact on water holding capacity, which can indicate that this protein has an essential role in maintaining the tight structure of muscles. However, in the present study, similar FN1 gene effects were not observed.

The last gene variations that were investigated in the present study were missense and frameshift variants of the $P N K D$ gene. However, according to the latest pig genome release (SusScrofa assembly 11.1) it was shown that both polymorphisms are located in intron region of PNKD gene. Thus, they are rather involved in the regulation of $P N K D$ expression than they alter amino acid sequence. Nevertheless, the function of the PNKD gene is still unknown, but there are some assumptions that the protein encoded by this gene could be a possible hydrolase [23]. However, STRING v.10 predicted a connection between the PNKD and MAPK3, ENO3, MYL12B, ILK and UBC proteins. MAPK3 participates in the MAPK/ERK pathway, which is essential for muscle cell proliferation and regeneration [26]. ENO3 is a protein called enolase 3 that is involved in muscle development in animals [27]. ILK, or integrin-linked kinase, takes part in the mediation of protein-protein interactions, thus connecting the ECM with intracellular cytoskeleton and signalling proteins [28]. In turn, UBC is a protein called ubiquitin $C$ that participates principally in protein degradation. As shown above, all proteins that potentially interact with PNKD are connected in different ways with muscle growth. In the present study, It was shown that rs329501722 variant affected water exudation, weight of loin, ham resilience and cohesiveness $(P<0.01)$, which was particularly apparent in Puławska pigs, a breed that was not under selective pressure. The pigs with the CC genotype showed lower water exudation and better texture parameters; thus, selection for this allele can affect the pork quality. In turn, the frameshift variant of $P N K D$ seems to influence meat yellowness, ham resilience and meat content traits $(P<0.05)$. Moreover, in the Polish Landrace breed, the effect on weight of loin, primary cuts and carcass yield was observed. Unfortunately, no publication has been written about the PNKD gene and its effect on any pig production traits, which makes it difficult to compare the results. However, in this manuscript were shown the interesting dependency between $P N K D$ mutations and pig productive traits, thus $P N K D$ effects should be further studied.

To summarize, the targeted enrichment DNA sequencing method could be used to preselection of molecular markers, but downstream association studies including large number animal populations are necessary. On the other hand, the investigated gene variants provided valuable information that could be used for the development of SNP microarrays to improve genomic estimated breeding value procedures in pigs.

Funding The targeted enrichment DNA sequencing method and partly association study was founded by Research Project No. 2013/09/D/ NZ9/02452 of Polish National Science Center and the rest analysis was founded by National Research Institute of Animal Production statutory activity "FBW program", research project No. 07-4.18.7.

\section{Compliance with ethical standards}

Conflict of interest None of the authors has a financial or other relationship with other people or organizations that may inappropriately influence this work.

Ethical approval The research will be performed on biological material derived from pigs maintained and slaughtered in the Test Pig Station (National Research Institute of Animal Production). In the Test Station pigs are slaughtered, dissected and after carcass evaluation, meat is standard intended for consumption. Therefore, our research does not require the approval of Animal Experimentation committee.

Open Access This article is distributed under the terms of the Creative Commons Attribution 4.0 International License (http://creativeco mmons.org/licenses/by/4.0/), which permits unrestricted use, distribution, and reproduction in any medium, provided you give appropriate credit to the original author(s) and the source, provide a link to the Creative Commons license, and indicate if changes were made. 


\section{References}

1. Li Y, Vinckenbosch N, Tian G (2010) Resequencing of 200 human exomes identifies an excess of low-frequency nonsynonymous coding variants. Nat Genet 42:969-982

2. Mertes F, El Sharawy A, Sauer S, van Helvoort JM, Van Der Zaag PJ, Franke A (2011) Targeted enrichment of genomic DNA regions for next-generation sequencing. Brief Funct Genomics 10:374-386

3. Ernst CW, Steibel JP (2013) Molecular advances in QTL discovery and application in pig breeding. Trends Genet 29:215-224

4. Milan D, Jeon J, Looft C, Amarger V, Robic A, Thelander M, Rogel-Gaillard C, Paul S, Iannuccelli N, Rask L, Ronne H, Lundström K, Reinsch N, Gellin J, Kalm E, Le Roy P, Chardon P, Andersson L (2000) A mutation in PRKAG3 associated with excess glycogen content in pig skeletal muscle. Science 288:1248-1251

5. Rothschild MF, Ciobanu DC, Malek M, Plastow G (2002) Novel PRKAG3 alleles and use of the same as genetic markers for reproductive and meat quality traits. [http://patentscope.wipo.int/webci te]. Patent publication 2002, WO/2002/020850

6. Robson RM, Huiatt TW (1983) Roles of the cytoskeletal proteins desmin, titin and nebulin in muscle. In: 37 th RMC Proceedings vol 37, pp 116-124

7. Starkey CP, Geesink GH, Collins D, Oddy VH, Hopkins DL (2016) Do sarcomere length, collagen content, $\mathrm{pH}$, intramuscular fat and desmin degradation explain variation in the tenderness of three ovine muscles? Meat Sci 113:51-58

8. Piórkowska K, Ropka-Molik K, Szmatoła T, Zygmunt K, Tyra M (2014) Association of a new mobile element in predicted promoter region of ATP-binding cassette transporter 12 gene (ABCA12) with pig production traits. Livest Sci 168:38-44

9. Tyra M, Żak G (2013) Analysis of the possibility of improving the indicators of pork quality through selection with particular consideration of intramuscular fat (MF) content. Ann Anim Sci $13: 33-44$

10. Ropka-Molik K, Bereta A, Tyra M, Różycki M, Piórkowska K, Szyndler-Nędza M, Szmatoła T (2014) Association of calpastatin gene polymorphisms and meat quality traits in pig. Meat Sci 97(2):143-150

11. Piórkowska, K., Żukowski, K., Ropka-Molik, K., \& Tyra, M. (2018). Deep sequencing of a QTL-rich region spanning 128$136 \mathrm{Mbp}$ of pig chromosome 15 . Gene 647, 268-275

12. Smit A, Hubley R, Green P (1996-2010) RepeatMaskerOpen-3.0. http://www.repeatmasker.org. Last Accessed 27 Jun 2011

13. Bassett JHD, Harvey CB, Williams GR (2003) Mechanisms of thyroid hormone receptor-specific nuclear and extra nuclear actions. Mol Cell Endocrinol 213:1-11

14. Onteru SK, Gorbach DM, Young JM, Garrick DJ, Dekkers JCM, Rothschild MF (2013). Whole genome association studies of residual feed intake and related traits in the pig. PLoS ONE 8:e61756

15. Piórkowska K, Żukowski K, Szmatoła T, Ropka-Molik K, Tyra M (2017) Transcript variants of a region on SSC15 rich in QTLs associated with meat quality in pigs. Ann Anim Sci 17:703-715

16. Das AK, Uhler MD, Hajra AK (2000) Molecular cloning and expression of mammalian peroxisomal trans-2-enoyl-coenzyme A reductase cDNAs. J Biol Chem 275:24333-24340

17. Huttlin EL, Ting L, Bruckner RJ, Gebreab F, Gygi MP, Szpyt J (2015) The BioPlex network: a systematic exploration of the human interactome. Cell 162:425-440

18. Sadkowski T, Ciecierska A, Majewska A, Oprządek J, Dasiewicz K, Ollikd M, Wicik Z, Motyl T (2014) Transcriptional background of beef marbling-novel genes implicated in intramuscular fat deposition. Meat Sci 97:32-41

19. Kärst S, Cheng R, Schmitt AO, Yang H, de Villena FP, Palmer AA, Brockmann GA (2011) Genetic determinants for intramuscular fat content and water-holding capacity in mice selected for high muscle mass. Mamm Genome 22:530-543

20. Piórkowska K, Tyra M, Ropka-Molik K, Podbielska A (2017) Evolution of peroxisomal trans-2-enoyl-CoA reductase (PECR) as candidate gene for meat quality. Livest Sci 201:85-91

21. Sanes JR, Cheney JM (1982) Laminin, fibronectin, and collagen in synaptic and extrasynaptic portions of muscle fiber basement membrane. J Cell Biol 93:442-451

22. Christopher RA, Judge SR, Vincent PA, Higgins PJ, McKeownLongo PJ (1999) The amino-terminal matrix assembly domain of fibronectin stabilizes cell shape and prevents cell cycle progression. J Cell Sci 112:3225-3235

23. https://www.genecards.org/

24. Cassar-Malek I, Passelaigue F, Bernard C, Léger J, Hocquette J-F (2007) Target genes of myostatin loss-of-function in muscles of late bovine foetuses. BMC Genomics 8:63

25. Ponsuksili S, Jonas E, Murani E, Phatsara C, Srikanchai T, Walz C, Schwerin M, Schellander K, Wimmers K (2008) Trait correlated expression combined with expression QTL analysis reveals biological pathways and candidate genes affecting water holding capacity of muscle. BMC Genomics 9:367

26. Elia D, Madhala D, Ardon E, Reshef R, Halevy O (2007) Sonic hedgehog promotes proliferation and differentiation of adult muscle cells: involvement of MAPK/ERK and PI3K/Akt pathways. BBA-Mol. Cell Res 1773:1438-1446

27. Peshavaria M, Day INM (1991). Molecular structure of the human muscle-specific enolase gene (EN03). Biochem J 275:427-443

28. Wu C, Dedhar S (2001) Integrin-linked kinase (ILK) and its interactors: a new paradigm for the coupling of extracellular matrix to actin cytoskeleton and signaling complexes. J Cell Biol 155:505-510 